\title{
The effect of novel coronavirus pandemic on tourism share prices
}

\author{
Venus Khim-Sen Liew
}

\begin{abstract}
Purpose - This paper aims to provide swift feedback to readers and investors on the early effect of novel coronavirus (COVID-19) pandemic outbreak on tourism industry.

Design/methodology/approach - Three leading consolidators of hotel accommodations, airline tickets and travel services in the tourism industry around the globe, namely, Booking Holdings Inc., Expedia Group and Trip.com Group Ltd. are chosen in this study. First, numerical description is performed on their shares prices and a set of control variables to compare their performances before and during the lockdown because of COVID-19 outbreak. Next, this paper estimates ordinary least squares models with and without exponential generalized autoregressive conditional heteroskedastic specification to establish the nature, significance and magnitude of the pandemic's early effect on the shares performance of these online travel companies (OTCS).
\end{abstract}

Findings - This paper discovers a rapid decline in the performance of tourism industry amid the pandemic outbreak, from the perspective of three leading OTCs, which derive their profits from tourists by providing them online hotel reservation, air-ticketing and packaged-tour business services around the globe. These significant adverse direct and indirect effects testify that tourism-related businesses are extensively locked down by the pandemic outbreak.

Research limitations/implications - Future studies are encouraged to examine each of the tourism sectors for individual effects.

Practical implications - This paper provides implications for investors to protect their wealth, and for policymakers to ensure sustainability of tourism industry in the pandemic outbreak and in the future.

Originality/value - From the perspective of corporate finance, this paper empirically quantifies the early effect of COVID-19 on tourism industry for a quick snapshot.

Keywords Stock market, Tourism industry, Novel coronavirus pandemic

Paper type Research paper

\section{Introduction}

Incontrovertibly, the recent outbreak of novel coronavirus (COVID-19) pandemic has locked down and dampened the world economy with immediate effect. Among others, tourismrelated businesses such as food and beverages, travel and hotel businesses are affected most of all and badly misshaped by it. Tourism industry has been growing substantially in China over the past few decades. International tourist arrivals to China had surged significantly from 230,000 people in 1978 (Lew, 1987) to 30.54 million people in 2018 (Thomala, 2020a). In the recent decade, tourism revenue in China grew from Yuan 1,155bn in 2008 to Yuan 5,128bn in 2018 [1]. This is equivalent to an average growth of $16.5 \%$ per annum. In the year 2018 itself, tourism industry accounted for some 3.9\% direct and 12.9\% total contribution to the gross domestic product (GDP) of China (Thomala, 2020a). From another perspective, Chinese tourists spent a total of US\$227bn (about Yuan 1,964bn) abroad in the same year. Indeed, China outbound tourism grew at an average growth of 24.5\% per year for the past decade (Thomala, 2020b). Moreover, tourism industry contributed to $10.4 \%$ of global GDP in 2019, and it supported some 319 million jobs or
Venus Khim-Sen Liew is based at the Faculty of Economics and Business, Universiti Malaysia Sarawak, Kota Samarahan, Malaysia.

Received 31 March 2020

Revised 24 May 2020

27 May 2020

Accepted 14 July 2020

() Venus Khim-Sen Liew. Published in Journal of Tourism Futures. Published by Emerald Publishing Limited. This article is published under the Creative Commons Attribution (CC BY 4.0) license. Anyone may reproduce, distribute, translate and create derivative works of this article (for both commercial and non-commercial purposes), subject to full attribution to the original publication and authors. The full terms of this license may be seen at http://creative commons.org/licences/by/4.0/ legalcode

The valuable suggestions and insightful thoughts from two anonymous reviewers and an associate editor of this journal are gratefully acknowledged, without implicating them in any remaining errors in my paper. 
equivalently $10 \%$ global employment (Turner and Jus, 2019). Hence, it can be said that this industry is important to not only the economy of China, but also the international tourism market.

Unfortunately, while the tourism industry is blooming, the recent outbreak of the COVID-19 pandemic has been particularly catastrophic for it. COVID-19 was first identified in Wuhan, China in December 2019 [2]. It then spreads rapidly to Asia and the rest of the world, at an explosively rate (Figure 1) [3]. As of March 30, 2020, there are a total of 723,732 confirmed coronavirus cases and 34,000 deaths (fatal rate $=4.7 \%$ ), and these numbers are growing every second with no sign of falling in the near time (Worldometers, 2020) [4].

This COVID-19 is transmitted from human to human and hence it is a huge threat to human and the world economy. To break the chain of virus transmission, China unprecedentedly locked down the Wuhan city of 11 million people and enforced movement control order in other nearby cities effective from January 23, 2020 (Crossley, 2020) [5]. Many countries followed suit to contain the viral outbreak of this pandemic with bans on intercity and international travel. Domestically, schools, universities as well as public offices and facilities were closed until further notice. Government servants were ordered to work from home, and private businesses were also strongly encouraged to implement work from home, if the operation could not be essentially stopped. As a result, the productivity of various sectors of the economy in China and the globe is greatly reduced. Aggregate demand in turn is affected because of weak purchasing power. Because of this, Oxford Analytica (2000) foresees that COVID-19 pandemic may cut the global growth by $2 \%$ in the early 2020 , whereas the Organization for Economic Co-operation and Development (OECD, 2020a) estimates that for each month of containment, there will be a $2 \%$ loss in annual GDP. Moreover, economic sectors that are directly affected by lockdown possibly account for $30-40 \%$ of the GDP in most economies, while the tourism industry alone is likely to face a $70 \%$ decrease in its output (OECD, 2020b).

Because of the extensive movement control order and bans on travels across the globe as well as fears of travels among the public ${ }^{[6],[7]}$, tourism industry is the first and foremost affected industry. In this regard, Jamal and Budke (2020) are swift to provide insightful perspective to readers on COVID-19 outbreak, with special attention given to the actions and reactions in the travel and tourism industry. They discussed the lessons learned from the past and provided recommendation for the industry to move forward. In this aspect, the current study attempts to empirically quantify the extent to which the tourism industry has been affected by this COVID-19 in the early stage. Specifically, this paper carefully chooses three typical tourism-related listed companies, in which their global businesses are

Figure 1 World total COVID-19 cases and deaths (January 1, 2020 to March 30, 2020)
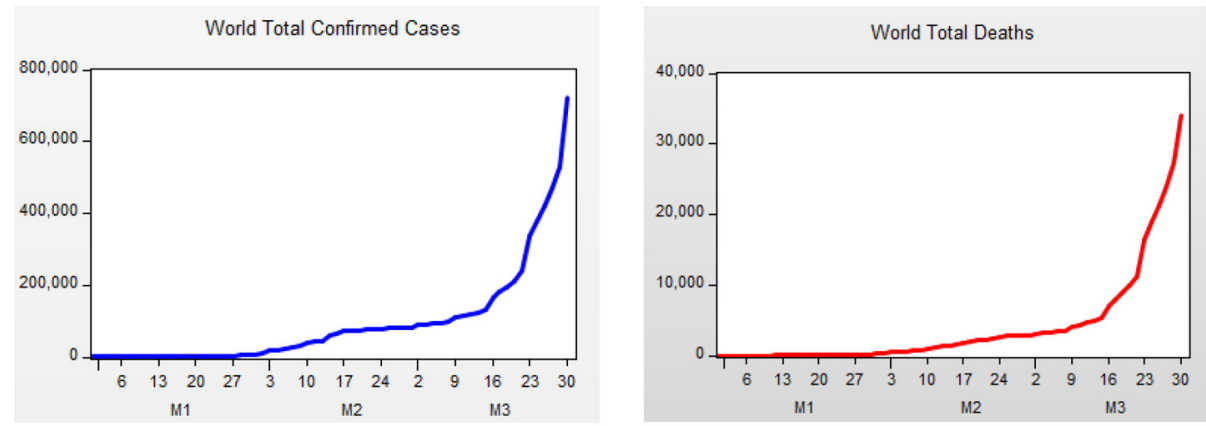

Source: Data obtained from Worldometers (2020) 
generally reflective of various key components of tourism industry, including travel services, tourism services, accommodation and transportation sectors. Namely, the three largest online travel companies (OTCs), Booking Holding Inc, Expedia Group and Trip.com Group Ltd., or in short Trip.com, are selected for analysis to provide swift feedback to interested readers, investors and policymakers [8].

Booking Holdings Inc. (formally known as Priceline.com) is an American OTC founded in 1996. It became a public traded company through initial public offering in 1999. Today, it operates in over 200 countries mainly via online travel platforms such as Booking.com, Priceline.com, Agoda.com, Kayak.com, Cheapflights, Rentalcars.com and OpenTable. It serves customers worldwide by allowing them to make travel reservations online with providers of travel services. It also provides accommodation, flight tickets and restaurant reservations and vacation packages. Most of its gross profits are generated from Booking. com, the world's leading brand for booking online accommodation reservations for about 2.6 million properties including hotels, motels, resorts, apartments and other unique places for rent. The company trades on the NASDAQ as BKNG with a market capitalization of $\$ 84.06 \mathrm{bn}$ at the end of 2019 [9].

Expedia Group is another American OTC found as a division of Microsoft in 1996. It was spun off as a public traded company in 1999. It has more than 200 traveling websites including Expedia.com, Hotels.com, trivago.com, Orbitz.com, HomeAway, hotwire, Travelocity, CarRentals.com, etc. in over 70 countries. It provides online reservation services to customers from over 2.8 million properties, 500 airlines, 175 car rental companies and other tourism activities providers. Majority of its sales come from online booking services for lodging. The company trades on the NASDAQ as EXPE with a market capitalization of $\$ 15.14 \mathrm{bn}$ at the end of 2019 [10].

On the other hand, Trip.com Group Ltd. was formerly known as Ctrip.com International, Ltd. It was incorporated in June 1999 in Shanghai. The company for a start provides for a nationwide travel-related online services such as hotel reservations, air-ticketing and package-tour businesses to independent business and leisure travelers in China. It managed to achieve and maintained positive net profits since the first half of 2002. By December 4, 2003, it was listed in NASDAQ Stock Exchange (Securities and Exchange Commission, 2003). Today, this online travel agency is one of the well-known and best travel brands in China and the world, providing services to some 400 million members around the globe. This leading consolidator of hotel accommodations and airline tickets in China was rebranded on October 25, 2019 to reflect its global perspective (Schaal, 2019). The company trades on the NASDAQ as TCOM with a market capitalization of $\$ 18.63 \mathrm{bn}$ at the end of $2019^{[11],[12]}$.

\section{Empirical models}

This study adopts regression model to quantify the effect on COVID-19 pandemic on the selected tourism share prices. The following regression model is estimated using the ordinary least squares (OLS) principle:

$$
\begin{aligned}
y_{t}= & \beta_{0}+\beta_{1} L D+\beta_{2} \Delta W N C C_{t}+\beta_{3} N A S D A Q_{t}+\beta_{4} S S E_{t}+\beta_{5} G P_{t} \\
& +\beta_{6} O P_{t}+\beta_{7} V I X_{t}+\varepsilon_{1 t},
\end{aligned}
$$

where $y_{t}$ denotes the tourism share price for Booking Holding Inc., Expedia Group or Trip. com Group Ltd. LD is the dummy for lockdown because of COVID-19, which assumes 0 for dates before January 23, 2020 and 1 otherwise [13]. $\triangle W N C C$ represents the change in the world daily new confirmed cases. NASDAQ, SSE, GP, OP and VIX represent the NASDAQ Composite Index, Shanghai Stock Exchange Composite Index, gold spot price, WTI Crude 
oil price and market volatility index, respectively. Meanwhile, subscript $t$ refers to daily observation and $\beta_{i}$ for $i=0,1, \ldots, 7$ stands for the respective parameter to be estimated.

The two variables of interest here are $\angle D$ and $\triangle W N C C$, and the other financial (NASDAQ and $S S E$ ) and commodity ( $O P$ and GP) variables are control variables. Notably, the sign of $\beta_{1}$ and $\beta_{2}$ is able to confirm the nature of COVID-19 effect on tourism stocks in specific and it serves to provide empirical evidence to the tourism industry in general. It is anticipated that the business revenues of tourism companies are adversely affected by the lockdown, and so the coefficient of $L D\left(\beta_{1}\right)$ should be negative for lower share price during the lockdown period. On the other hand, a positive (negative) change in $\triangle W N C C$ means more (less) confirmed cases compared to the previous day. A rational investor would take negative change as favorable news and positive change otherwise. Thus, $\beta_{2}<0$ is expected. Moreover, the magnitude of $\beta_{1}$ and $\beta_{2}$ is capable of revealing the profoundness of the COVID-19 effect on tourism stocks in specific. Notably, Albulescu (2020) finds that new COVID-19 cases reported outside China has significant positive impact on VIX. Hence, the indirect impact of COVID-19 on tourism share price may be channeled through VIX and so it is included in this study.

Notably, $\varepsilon_{t} \sim N(0,1)$ denotes the residual series with the assumption of zero mean and unit variance, that is, it follows the standard normal distribution theory. Nonetheless, it is common in empirical research to observe violation of this assumption, such that $\varepsilon_{t} \sim \mathrm{N}\left(0, \sigma_{t}^{2}\right)$, where $\sigma_{t}^{2}$ is the heteroscedastic variance of $\varepsilon_{t}$. Essentially, this violation can be well-taken care of by including the following exponential general autoregressive conditional heteroscedasticity (EGARCH) $(1,1)$ specification in equation (1) [14]:

$$
\log \hat{\sigma}_{t}^{2}=\phi_{0}+\phi_{1}\left(\left|\hat{\varepsilon}_{t-1} / \hat{\sigma}_{t-1}\right|-\sqrt{2 / \pi}\right)+\phi_{2}\left(\hat{\varepsilon}_{t-1} / \hat{\sigma}_{t-1}\right)+\phi_{3} \log \hat{\sigma}_{t-1}^{2}
$$

In equation (2), $\phi_{2}$ is an asymmetry parameter. If $\phi_{2} \neq 0$, then positive (such as sign of declining rate of change in the world daily confirmed cases) and negative (such as the unprecedented lockdown) COVID-19 news/shocks have asymmetric effect on tourism stock price. If $\phi_{2}=0$, then there is no asymmetrical behavior detected. $\phi_{3}$ is the persistence parameter. Larger $\phi_{3}$ implies COVID-19 shocks have persistent effect on tourism stock price, while smaller $\phi_{3}$ indicates temporary effect.

For the ease of referencing, equation (1) is known as Model 1, while equation (1) with EGARCH $(1,1)$ specification is denoted as Model 2. Furthermore, Model 3 where VIX in Model 2 is replaced with the share prices of two other companies from the same industry is estimated to study the intra-industry spillover effect, if any. It is expected that their prices will exhibit co-movement with respect to news or shocks related to COVID-19 that will affect the tourism industry as a whole. Hence, their coefficients should be positive. Having said that, a negative coefficient indicates that the two companies are regarded as substitutes by investors. Finally, this study also estimates Model 4 which is Model 2 augmented with the share prices of two other tourism companies. A valid model for interpretation will have to satisfy the assumptions of normality, no autocorrelation and no heteroscedasticity effects in the estimated model's residuals. If there exist few valid models, the best model will be selected from the model that has the highest adjusted $R^{2}$ and the smallest Akaike information criterion (AIC).

\section{Data and findings from numerical description}

Daily data set spanning from October 2, 2019 to March 27, 2020 is used in this study to provide a swift feedback on the impact of COVID-19 in the early stage. The finance data set is obtained from Investing.com, while observations for the world daily new coronavirus cases are obtained from Worldometers (2020). A time-series plot of multiple graphs of the variables is given in Figure 2. The graphs exhibit different market reactions on the outbreak 
of COVID-19. Overall, tourism share prices and the overall US and China share market performances as represented by NASDAQ composite index and Shanghai Stock Exchange Composite indices, respectively, were all down in the lockdown period. Remarkably, Booking Holdings Inc. and Trip.com Group Ltd. share prices started to fall about eight trading days before the lockdown was enforced [15]. In sharp contrast, Expedia Group price only fell slightly in the Wuhan lockdown period. Nevertheless, it climbed to a threemonth record high at $\$ 130.80$, on February 6, 2020 before it started to fall deeply, together with the other two tourism shares.

The descriptive statistics as shown in Table 1 reveal that overall, the sample maximum and average values are all consistently lower in the lockdown period (January 23, 2020 and onwards) for Booking Holdings Inc., Expedia Group, Trip.com Group Ltd. share prices, Shanghai Stock Exchange Composite Index and oil price, compared to the before lockdown period (before January 23, 2020). Particularly, the mean share prices of Booking Holdings Inc., Expedia Group and Trip.com Ltd. are reduced by $\$ 294.013, \$ 21.598$ and $\$ 3.356$, respectively, in the lockdown period. In sharp contrast, the sample maximum and average values are higher in the lockdown period for NASDAQ Composite Index and gold. It is also worth noting that the sample standard deviations are all higher in the lockdown period with no exception. This serves to provide empirical evidence that all shares and commodities markets considered in this study are substantially more volatile because of the pandemic outbreak. The extent of the pandemic effect varies across markets, however. The markets are $6.5,2.8,2.9,4.0,2.7,2.6$ and 6.9 times more versatile in the lockdown

\section{Figure 2 Time-series plot of variables}
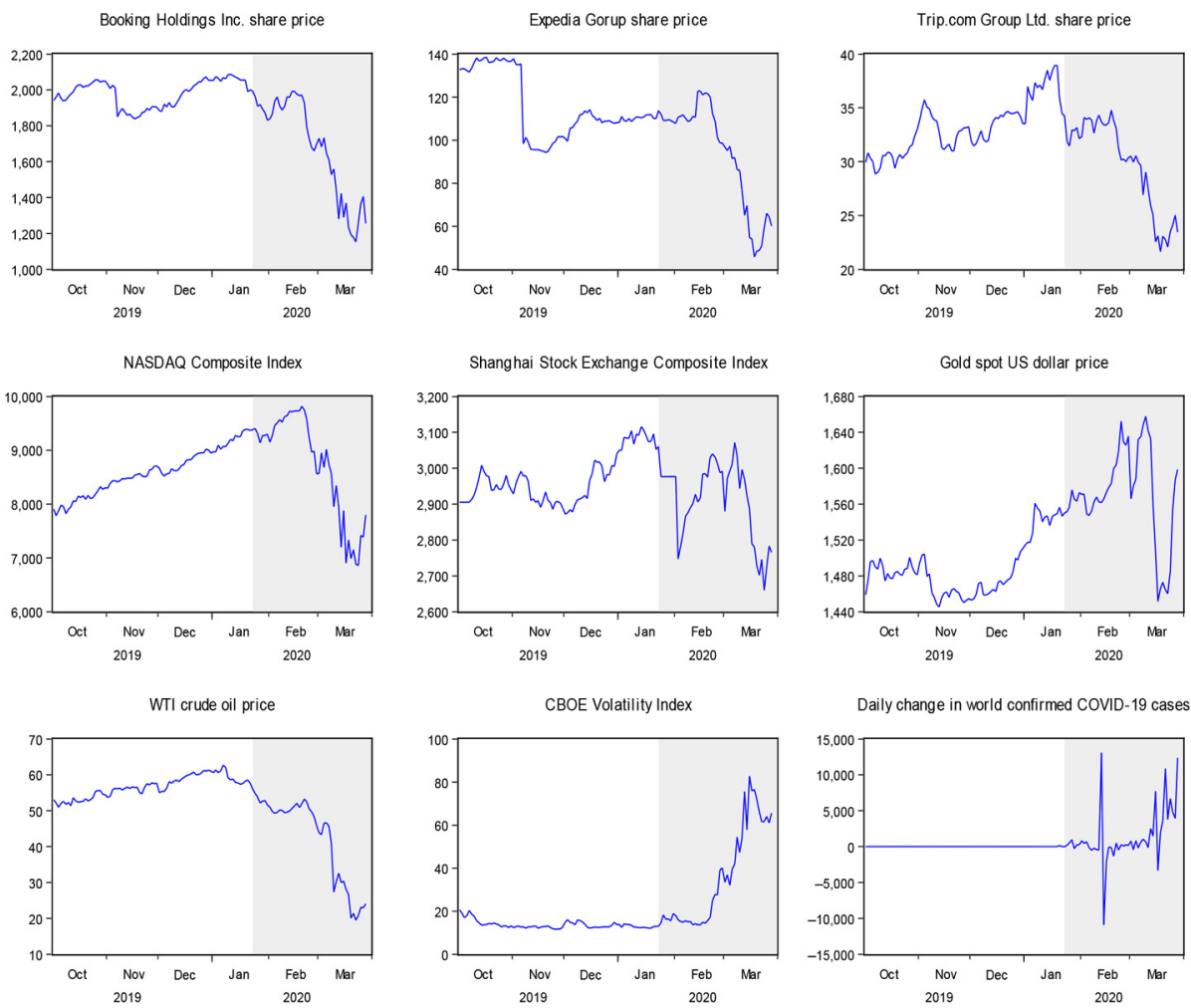

Daily change in world confirmed COVID-19 cases

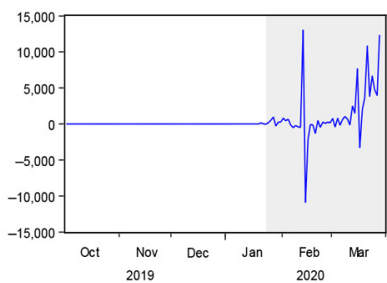

Note: Shaded area shows observations after the Wuhan lockdown imposition 
Table 1 Descriptive statistics

\begin{tabular}{|c|c|c|c|c|c|c|c|}
\hline Statistics & BOOK & EXPE & TRIP & NASDAQ & SSE & GP & OP \\
\hline Before lockdown: & \multicolumn{7}{|c|}{ October 1, 2019 to January 22, 2020 (82 observations) } \\
\hline Maximum & 2086.900 & 138.480 & 38.940 & 9388.940 & 3115.570 & 1573.990 & 64.920 \\
\hline Minimum & 1838.000 & 94.310 & 28.850 & 7785.250 & 2871.980 & 1454.350 & 52.200 \\
\hline Mean & 1981.713 & 115.651 & 33.185 & 8604.806 & 2970.850 & 1496.681 & 57.465 \\
\hline Standard deviation/day & 0.905 & 0.185 & 0.031 & 5.205 & 0.839 & 0.398 & 0.036 \\
\hline Skewness & -0.419 & 0.388 & 0.469 & 0.052 & 0.596 & 0.847 & 0.069 \\
\hline Kurtosis & -1.203 & -1.359 & -0.484 & -0.811 & -0.834 & -0.321 & -0.568 \\
\hline Lockdown period: & \multicolumn{7}{|c|}{ January 23, 2020 to March 27, 2020 (47 observations) } \\
\hline Maximum & 1993.200 & 122.800 & 34.790 & 9817.180 & 3071.680 & 1680.200 & 55.620 \\
\hline Minimum & 1152.200 & 45.650 & 21.630 & 6860.670 & 2660.170 & 1471.000 & 21.530 \\
\hline Mean & 1687.700 & 94.053 & 29.829 & 8703.298 & 2907.103 & 1590.673 & 43.077 \\
\hline Standard deviation/day & 5.875 & 0.514 & 0.089 & 20.563 & 2.295 & 1.033 & 0.245 \\
\hline Skewness & -0.620 & -0.766 & -0.708 & -0.683 & -0.654 & -0.292 & -0.798 \\
\hline Kurtosis & -1.063 & -0.830 & -0.945 & -0.969 & -0.778 & -0.076 & -1.066 \\
\hline
\end{tabular}

Notes: BOOK, EXPE and TRIP represent the share prices of Booking Holding Inc., Expedia Group, Trip.com Group Ltd., respectively. NASDAQ, SSE, GP and OP denote NASDAQ Composite Index, Shanghai Stock Exchange Composite Index, gold spot price and WTI crude oil price, in that sequence

period for Booking Holdings Inc., Expedia Group, Trip.com Group Ltd. share prices, NASDAQ Composite Index, Shanghai Stock Exchange Composite Index, gold price and oil price, in that order.

Panel A of Table 2 shows the periodic percentage change in the stocks and commodities variables for different sub-sample periods and different months. Over the full sample period, investors who bought shares and commodities on October 2, 2019 and sold them on the March 27, 2020 would experience a realized loss of 31.058\%, 55.163\%, 10.873\%, $1.389 \%, 4.312 \%$ and $48.624 \%$ for BOOK, EXPE, TRIP, NASDAQ, SSE and WTI crude oil, respectively [16], [17]. On the other hand, they would make a profit of $12.017 \%$ on gold.

Further analysis on the breakdown of these observations based on sub-samples before and during the Wuhan lockdown uncovers striking empirical facts. Particularly, investors who bought these shares and commodities on October 2, 2019 and sold them on January 22, 2020 would all make some profits, except for EXPE [18]. Remarkably, investors could make $15.449 \%$ and $1.122 \%$ profits with TRIP and BOOK, respectively, whereas the return on EXPE is $-17.833 \%$ (a loss) in the same period. In sharp contrast, investors would realize a loss by buying the shares on January 23, 2020 and selling them on March 27, 2020, except for gold [19]. As of tourism shares of specific interest, the return on BOOK $(-29.460 \%)$ and $\operatorname{TRIP}(-26.970 \%)$ are comparable in magnitude, while EXPE suffers a greater extend of negative return during this lockdown period, which is a loss of $43.366 \%$.

As the periods are of different lengths, the average daily percentage change in Panel A is divided by the number of trading days in the corresponding period for standardization. The outputs are reported in Panel B of Table 2. It is observed from the during/before ratio in Panel B that the average daily returns during the lockdown period are larger in magnitude compared to the period before lockdown. In particular, BOOK and TRIP share prices suffer an average daily loss of $0.627 \%$ and $0.574 \%$, respectively, during lockdown and that is about 46 times and 3 times their respective daily gains before lockdown. It implies that investors of these two tourism shares lose money faster during lockdown than they made money before lockdown. As for investors who have a long position with EXPE, their investment value would reduce by $0.923 \%$ per day during the lockdown period and that is four times the average daily loss before the lockdown. Thus, the main lesson learned from Table 2 is that, as far as tourism shares are concerned, the negative impact of lockdown because of COVID-19 on them is substantial. In future, investors who have long position on 
Table 2 Percentage change of stock and commodity variables

\begin{tabular}{|c|c|c|c|c|c|c|c|}
\hline Variable & BOOKING & EXPEDIA & TRIP & NASDAQ & SSE & GP & $\mathrm{OP}$ \\
\hline \multicolumn{8}{|c|}{$\begin{array}{l}\text { Panel A: Overall change } \\
\text { Periodic analysis }\end{array}$} \\
\hline Full sample(\%) & -31.058 & -55.163 & -10.873 & -1.389 & -4.312 & 12.017 & -48.624 \\
\hline Before(\%) & 1.122 & -17.833 & 15.449 & 18.651 & 5.355 & 5.405 & 3.774 \\
\hline During(\%) & -29.460 & -43.366 & -26.970 & -17.069 & -7.110 & 4.418 & -59.061 \\
\hline \multicolumn{8}{|l|}{ Monthly analysis } \\
\hline October, 2019(\%) & -3.620 & -24.195 & 11.025 & 10.071 & -0.534 & -1.396 & 7.327 \\
\hline November, 2019(\%) & -6.299 & -26.226 & -1.628 & 3.328 & -2.915 & -3.246 & -1.231 \\
\hline December, 2019(\%) & 8.984 & 5.207 & 7.335 & 4.722 & 6.061 & 3.758 & 9.341 \\
\hline January, $2020 b(\%)$ & -2.605 & 2.713 & 1.748 & 4.583 & 0.349 & 2.743 & -8.380 \\
\hline January, 2020 a(\%) & -8.163 & -6.217 & -4.643 & -2.675 & 0.000 & 1.719 & -7.282 \\
\hline February, 2020(\%) & -7.792 & -6.122 & -8.516 & -7.613 & 4.867 & 0.551 & -9.523 \\
\hline March, 2020(\%) & -18.681 & -17.967 & -33.413 & -12.898 & -6.935 & 2.619 & -52.364 \\
\hline \multicolumn{8}{|c|}{$\begin{array}{l}\text { Panel B: Average daily change } \\
\text { Periodic analysis }\end{array}$} \\
\hline Full sample(\%) & -0.241 & -0.428 & -0.084 & -0.011 & -0.033 & 0.093 & -0.377 \\
\hline Before(\%) & 0.014 & -0.217 & 0.188 & 0.227 & 0.065 & 0.066 & 0.046 \\
\hline During(\%) & -0.627 & -0.923 & -0.574 & -0.363 & -0.151 & 0.094 & -1.257 \\
\hline Before/during(\%) & -45.796 & 4.243 & -3.046 & -1.597 & -2.317 & 1.426 & -27.301 \\
\hline \multicolumn{8}{|l|}{ Monthly analysis } \\
\hline October, 2019(\%) & -0.157 & -1.052 & 0.479 & 0.438 & -0.023 & -0.061 & 0.319 \\
\hline November, 2019(\%) & -0.300 & -1.249 & -0.078 & 0.158 & -0.139 & -0.155 & -0.059 \\
\hline December, 2019(\%) & 0.408 & 0.237 & 0.333 & 0.215 & 0.276 & 0.171 & 0.425 \\
\hline January, 2020 b(\%) & -0.163 & 0.170 & 0.109 & 0.286 & 0.022 & 0.171 & -0.524 \\
\hline January, $2020 a(\%)$ & -1.166 & -0.888 & -0.663 & -0.382 & 0.000 & 0.246 & -1.040 \\
\hline February, 2020(\%) & -0.390 & -0.306 & -0.426 & -0.381 & 0.243 & 0.028 & -0.476 \\
\hline March, 2020(\%) & -0.934 & -0.898 & -1.671 & -0.645 & -0.347 & 0.131 & -2.618 \\
\hline
\end{tabular}

Notes: BOOK, EXPE and TRIP represent the share prices of Booking Holding Inc., Expedia Group, Trip.com Group Ltd., respectively. NASDAQ, SSE, GP and OP denote NASDAQ Composite Index, Shanghai Stock Exchange Composite Index, gold spot price and WTI crude oil price, in that sequence. $b$ stands for dates before January 23, 2020. a stands for January 23, 2020 and after. "Before/During" shows the ratio of average daily return during lockdown to average daily return before lockdown

tourism shares should take profit like the case of BOOK and TRIP or cut loss as in the case of EXPE whenever there is any early news on the outbreak of human infectious disease, to avoid bigger loss.

From the perspective of monthly analysis, investors longing for BOOK, EXPE, TRIP, SSE, GP and $O P$ were experiencing a price slide during the month of November 2019, while in the same month NASDAQ continued its October price ride. Notably, returns on both stock and commodities markets were positive during the month of December. They maintained positive in January prior to the lockdown, with the exception of $B O O K$ and $O P$ which turned negative in returns in the same period. On the other hand, returns on all stocks and commodities are negative for all the months covered in the lockdown period with gold remains as an exception. There is no sign that gold price is negatively affected by the COVID-19 or the lockdown. In fact, returns on gold are consistently positive right from the month of December 2019 to March 2020. This reveals that gold could act as safe haven for investors of tourism shares during pandemic crisis. As such, in facing any threat of disease outbreak in the future, they may protect their investment value by getting out of the shares market and invest in the gold market. As for another counter in the commodities market, WTI crude oil price dropped by $8.380 \%$ in January 2020 before the lockdown. Its price continued to slide until March, when it fell by $52.364 \%$ in that month alone, in line to the drastic drop in the tourism share prices and the general market indices [20]. 


\section{Findings from empirical modeling}

The four OLS regression models are estimated and the results for Booking Holding Inc, (BOOK), Expedia Group (EXPE) and Trip.com Group Ltd. (TRIP) are summarized in Tables 3, 4 to 5, respectively [21].

Table 3 shows that Model 1 does not satisfied the assumptions of normality, no autocorrelation and no heteroscedasticity effects in its estimated residuals. Meanwhile, all the other three estimated models do not have any of these problems at $5 \%$ significance level. As such the best model based on adjusted $R^{2}$ is Model 3 but AlC suggests that Model 4 is the best. In this situation, Model 4 is selected for interpretation as Model 3 actually has a modeling problem of non-normal residuals at $10 \%$ significance level.

Model 4 shows that the share price of Booking Holding Inc. is significantly affected by the Wuhan lockdown $(L D)$ to contain COVID-19 outbreak, while change in daily confirmed COVID-19 cases ( $\triangle W N C C$ ) has zero impact on it. On average, the share price reduces by $\$ 37.490$ during the lockdown period compared to the period before it, ceteris paribus.

Besides the COVID-19 variables, Booking Holding Inc. share price has significant positive relationship with the NASDAQ Composite Index. It implies that BOOK is following the direction of the overall market sentiments and represented by NASDAQ. On the other hand, the share price is negatively related to gold price (GP). It confirms that gold is a safe haven for Booking Holding Inc. stock. One the other perspective, BOOK and market volatility index

Table 3 Regression results for Booking Holding Inc.

\begin{tabular}{|c|c|c|c|c|c|c|c|c|}
\hline \multirow{3}{*}{$\begin{array}{l}\text { Variable } \\
\text { Constant } \\
\text { LD }\end{array}$} & \multicolumn{2}{|c|}{$\begin{array}{l}\text { Coefficient } \\
\text { Model } 1\end{array}$} & \multicolumn{2}{|c|}{$\begin{array}{l}\text { Coefficient } \\
\text { Model } 2\end{array}$} & \multicolumn{2}{|c|}{$\begin{array}{l}\text { Coefficient } \\
\text { Model } 3\end{array}$} & \multicolumn{2}{|c|}{$\begin{array}{l}\text { Coefficient } \\
\text { Model } 4\end{array}$} \\
\hline & 709.977 & 0.077 & $1231.105^{\star \star}$ & 0.000 & $605.203^{\star \star}$ & 0.000 & $950.422^{\star *}$ & 0.000 \\
\hline & 60.492 & 0.159 & $53.011^{* *}$ & 0.000 & $71.540^{\star *}$ & 0.000 & $37.490^{\star \star}$ & 0.002 \\
\hline$\triangle W N C C$ & 0.004 & 0.200 & 0.001 & 0.128 & 0.001 & 0.460 & 0.000 & 0.959 \\
\hline$N A S D A Q$ & 0.005 & 0.870 & 0.002 & 0.782 & $0.062^{\star \star}$ & 0.000 & $0.042^{\star \star}$ & 0.000 \\
\hline SSE & 0.272 & 0.153 & $0.263^{* *}$ & 0.000 & 0.054 & 0.129 & 0.064 & 0.231 \\
\hline$G P$ & 0.350 & 0.399 & 0.113 & 0.166 & $0.369^{\star \star}$ & 0.000 & $0.331^{\star \star}$ & 0.000 \\
\hline$O P$ & 2.119 & 0.543 & 0.301 & 0.769 & $2.366^{\star *}$ & 0.003 & 0.532 & 0.301 \\
\hline \multicolumn{8}{|l|}{ BOOK } & 0.000 \\
\hline EXPE & & & & & $5.124^{\star \star}$ & 0.000 & $4.526^{\star \star}$ & 0.000 \\
\hline TRIP & & & & & $15.183^{\star \star}$ & 0.000 & $14.046^{* *}$ & 0.000 \\
\hline \multicolumn{9}{|c|}{ Variance equation } \\
\hline$\alpha_{O}$ & & & $1.814^{*}$ & 0.023 & $4.048^{\star *}$ & 0.009 & $4.469^{\star *}$ & 0.003 \\
\hline$\alpha_{1}$ & & & $2.133^{\star *}$ & 0.000 & $1.786^{\star \star}$ & 0.000 & $1.924^{\star \star}$ & 0.000 \\
\hline$\alpha_{2}$ & & & $0.687^{*}$ & 0.030 & 0.273 & 0.307 & 0.081 & 0.788 \\
\hline$\alpha_{3}$ & & & $0.503^{\star *}$ & 0.000 & 0.194 & 0.355 & 0.109 & 0.546 \\
\hline \multicolumn{9}{|l|}{ Diagnostic } \\
\hline$N$ & 127 & & 127 & & 127 & & 127 & \\
\hline$R^{2}$ & 0.929 & & 0.899 & & 0.971 & & 0.969 & \\
\hline Adjusted $R^{2}$ & 0.924 & & 0.893 & & 0.969 & & 0.967 & \\
\hline$A / C$ & 11.172 & & 10.652 & & 9.932 & & 9.923 & \\
\hline$J-B$ & 3.753 & 0.153 & 1.178 & 0.56 & 5.675 & 0.059 & 4.454 & 0.108 \\
\hline$A R C H$ & $30.211^{\star *}$ & 0.000 & 0.820 & 0.37 & 0.021 & 0.885 & 0.119 & 0.730 \\
\hline$Q[1]$ & $25.412^{\star *}$ & 0.000 & 0.825 & 0.364 & 0.022 & 0.883 & 0.124 & 0.725 \\
\hline$Q[20]$ & $71.112^{\star \star}$ & 0.000 & 8.811 & 0.985 & 16.715 & 0.671 & 20.551 & 0.424 \\
\hline
\end{tabular}

Notes: BOOK, EXPE and TRIP represent the share prices of Booking Holding Inc., Expedia Group, Trip.com Group Ltd., respectively. NASDAQ, SSE, GP and OP denote NASDAQ Composite Index, Shanghai Stock Exchange Composite Index, gold spot price and WTI crude oil price, in that sequence. The probability value, $p$ is computed based on White heteroskedasticity-consistent standard errors and covariance, while $J-B$ stands for Jarque-Bera normality test. $A R C H$ denotes heteroscedasticity test for autoregressive conditional heteroscedasticity effect. $Q[1]$ and $Q[20]$ denote the Q-statistics of correlogram standardized squared residuals of lag 1 and 20 , respectively, for the detection of autocorrelation. ${ }^{* *}$ and * denote that the variable is significant at $1 \%(p<0.01)$ and $5 \%(p<0.05)$, respectively 
$(V I X)$ are negatively related. This means the higher the VIX, the lower is the share price and vice versa. Hence, investors should monitor the VIX and avoid tourism shares when the market is very volatile. Meanwhile, Chia et al. (2020) shows that Malaysia stock market indices are adversely affected by VIX. In this aspect, Albulescu (2020) finds that new COVID-19 cases reported outside China has significant positive impact on VIX. Hence, the indirect impact of COVID-10 on tourism share prices may be channeled through VIX. As such, the finding of VIXs negative impact on BOOK share price may be taken as evidence of indirect impact of COVID-19 on tourism share. Note that other variables have no significant impact on BOOK.

From the estimated variance equation of Model 4 , it is seen that the estimated $\phi_{2}$ is statistically indifferent from zero. Therefore, positive and negative COVID-19 shocks have symmetric effect on tourism stock price as represented by BOOK. Moreover, the estimated $\phi_{3}$ is also insignificantly different from zero, implying that COVID-19 shocks have zero memory effect on this tourism stock price. In other words, today's BOOK stock price is determined by todays' news including COVID-19 related reports, but it will not be affected by news announced yesterday and before.

Table 4 displays that the best-fitted model for Expedia Group (EXPE) is Model 4, which has passed all the diagnostic tests. Moreover, it has the highest adjusted $R^{2}$ and the smallest AIC. This model reveals that the Wuhan lockdown has a positive and statistically significant impact on EXPE share price. The results show that, on average, its share price increases by

Table 4 Regression results for Expedia group

\begin{tabular}{|c|c|c|c|c|c|c|c|c|}
\hline \multirow{3}{*}{ Variable } & \multicolumn{2}{|c|}{$\begin{array}{l}\text { Coefficient } \\
\text { Model } 1\end{array}$} & \multicolumn{2}{|c|}{$\begin{array}{l}\text { Coefficient } \\
\text { Model } 2\end{array}$} & \multicolumn{2}{|c|}{$\begin{array}{l}\text { Coefficient } \\
\text { Model } 3\end{array}$} & \multicolumn{2}{|c|}{$\begin{array}{l}\text { Coefficient } \\
\text { Model } 4\end{array}$} \\
\hline & 20.934 & 0.685 & $38.173^{\star \star}$ & 0.000 & $117.936^{\star \star}$ & 0.000 & $73.667^{\star \star}$ & 0.000 \\
\hline & 11.080 & 0.074 & $1.031^{\star \star}$ & 0.008 & $8.339^{* *}$ & 0.003 & $9.399^{* *}$ & 0.002 \\
\hline$\triangle W N C C$ & 0.000 & 0.212 & $0.000^{* *}$ & 0.000 & 0.000 & 0.498 & 0.000 & 0.405 \\
\hline$N A S D A Q$ & $0.025^{\star \star}$ & 0.000 & $0.005^{\star \star}$ & 0.000 & $0.015^{\star *}$ & 0.000 & $0.016^{\star *}$ & 0.000 \\
\hline SSE & 0.024 & 0.382 & $0.007^{\star \star}$ & 0.000 & $0.023^{\star *}$ & 0.005 & 0.003 & 0.699 \\
\hline$G P$ & $0.164^{\star \star}$ & 0.004 & $0.028^{\star \star}$ & 0.000 & 0.120 ** & 0.000 & $0.117^{\star \star}$ & 0.000 \\
\hline$O P$ & 0.338 & 0.565 & $0.273^{\star \star}$ & 0.000 & 0.111 & 0.442 & 0.208 & 0.248 \\
\hline VIX & $1.630^{\star \star}$ & 0.000 & $0.585^{\star \star}$ & 0.000 & & & $0.504^{\star \star}$ & 0.000 \\
\hline BOOK & & & & & $0.160^{\star *}$ & 0.000 & $0.133^{\star \star}$ & 0.000 \\
\hline \multicolumn{9}{|l|}{ EXPE } \\
\hline TRIP & & & & & $2.058^{\star *}$ & 0.000 & $2.425^{\star \star}$ & 0.000 \\
\hline \multicolumn{9}{|c|}{ Variance equation } \\
\hline$\alpha_{0}$ & & & $1.529^{\star *}$ & 0.000 & 0.448 & 0.486 & 0.036 & 0.947 \\
\hline$\alpha_{1}$ & & & $2.438^{\star \star}$ & 0.000 & $1.789^{\star *}$ & 0.000 & $1.363^{\star \star}$ & 0.001 \\
\hline$\alpha_{2}$ & & & 0.071 & 0.814 & 0.219 & 0.428 & 0.008 & 0.969 \\
\hline$\alpha_{3}$ & & & $0.802^{\star *}$ & 0.000 & $0.425^{\star}$ & 0.023 & $0.666^{\star *}$ & 0.000 \\
\hline \multicolumn{9}{|l|}{ Diagnostic } \\
\hline$N$ & 127 & & 127 & & 127 & & 127 & \\
\hline$R^{2}$ & 0.769 & & 0.460 & & 0.894 & & 0.911 & \\
\hline Adjusted $R^{2}$ & 0.755 & & 0.429 & & 0.887 & & 0.904 & \\
\hline$A / C$ & 7.625 & & 6.135 & & 6.438 & & 6.357 & \\
\hline$J-B$ & 0.269 & 0.874 & $7.777^{\star}$ & 0.020 & 5.592 & 0.061 & 3.34 & 0.219 \\
\hline$A R C H$ & $32.329^{\star *}$ & 0.000 & 0.099 & 0.754 & 0.029 & 0.865 & 0.333 & 0.564 \\
\hline$Q[1]$ & $26.762^{\star *}$ & 0.000 & 0.100 & 0.751 & 0.030 & 0.852 & 0.156 & 0.693 \\
\hline$Q[20]$ & $117.140^{* *}$ & 0.000 & 17.775 & 0.602 & 13.695 & 0.846 & 15.134 & 0.769 \\
\hline
\end{tabular}

Notes: BOOK, EXPE and TRIP represent the share prices of Booking Holding Inc., Expedia Group, Trip.com Group Ltd., respectively. NASDAQ, SSE, GP and OP denote NASDAQ Composite Index, Shanghai Stock Exchange Composite Index, gold spot price and WTI crude oil price, in that sequence. The probability value, $p$ is computed based on White heteroskedasticity-consistent standard errors and covariance, while $J-B$ stands for Jarque-Bera normality test. $A R C H$ denotes heteroscedasticity test for autoregressive conditional heteroscedasticity effect. $Q[1]$ and $Q[20]$ denote the Q-statistics of correlogram standardized squared residuals of lag 1 and 20 , respectively, for the detection of autocorrelation. ${ }^{*}$ and * denote that the variable is significant at $1 \%(p<0.01)$ and $5 \%(p<0.05)$, respectively 
\$9.399 during the lockdown period compared to the period before lockdown, ceteris paribus. Both EXPE and TRIP have similar capital size and are traded in NASDAQ stock market. Remarkably, TRIP share price fell tremendously after the imposition of Wuhan lockdown, while EXPE share price was rising for the first two weeks after the Wuhan lockdown such that it even managed to register for a three-month high on February 6, 2020. In the beginning of the lockdown, tourism counter investors possibly had treated EXPE, an American-based OTC as substitute of TRIP, a China-based OTC, thinking that the lockdown may only have impact on China's tourism industry. This substitute effect may also be observed from the significant negative coefficient of TRIP, which reveals that a dollar change in TRIP share price can be associated to a change of $\$ 2.425$ for EXPE in the opposite direction, ceteris paribus. Other variables that had significant negative impacts on EXPE are NASDAQ, SSE and VIX, whereas GP has a significant positive relationship with EXPE. Similar to the case of BOOK, the finding on VIX indicates that COVID-19 has indirect effect on EXPE. On the other hand, $\triangle W N C C$ and $O P$ have insignificant direct impact on EXPE.

On the estimated variance equation of Model 4 , the estimated $\phi_{2}$ is statistically indifferent from zero, while the estimated $\phi_{3}$ is significantly different from zero at $1 \%$ significant level. Thus, positive and negative COVID-19 shocks have symmetric effect on this tourism stock price. But the shocks will be transmitted into the future price of EXPE. Moreover, it can be computed that it takes about two days only for the shocks to be reduced to one-half of their original size [22]. As such, shocks can be considered to have short-memory impact on the share price of EXPE.

Table 5 shows that, consistent with the other two tourism OTCs, Model 4 is the best-fitted model for Trip.com Group Ltd. This model not only has met the modeling requirements of normal, non-autocorrelated and no heteroscedastic residuals, but it also has the largest adjusted $R^{2}$ and the smallest $A / C$ value.

It is clear from the estimated Model 4 that, the coefficient of $L D$ is -2.102 and it is significant at $1 \%$ significance level. The significant negative sign provides us with empirical evidence that the Wuhan lockdown because of the COVID-19 outbreak has exerted significant adverse effect on Trip.com Group Ltd., in which the company essentially derives its profits from tourists by providing them online hotel reservation, air-ticketing and packaged-tour business services around the globe and around the clock. A series of global lockdown started from January 23, 2020 in Wuhan extensively limits tourists travel activities be it for business, study or leisure.

Similar to the other two tourism shares, the change in world confirmed coronavirus cases essentially has insignificant effect on the share price of Trip.com Group Ltd. Probably, after the Wuhan lockdown had been imposed, investors expected that tourists are unable or even unwilling to travel during this emergency period. As such, they do not bother about the change in coronavirus cases and so the share price is unaffected at all.

On the control variables, only $N A S D A Q$ was statistically significant at $1 \%$ level. It means share price of Trip.com Group Ltd. is related to the NASDAQ Composite Index. The results show that, on average, a 100 points increase (increase) in NASDAQ can be associated to 20 cents increase (decrease) in TRIP, other things remain unchanged. In addition, Model 4 also suggests that TRIP had significant positive relation with GP and $B O O K$. Moreover, a $\$ 100$ increase (decrease) in GP and BOOK, can be related to, on average, a $\$ 1.30$ and $\$ 1.50$ increase (decrease) respectively in TRIP, ceteris paribus. In contrast, a $\$ 10$ increase (decrease) in $O P$ can be associated to 67 cents decrease (increase) in TRIP, correspondingly. Note that the estimated coefficient of EXPE has a significant negative sign. Thus, consistent with the results reported in Table 4, investors treat TRIP and EXPE as substitute counters in NASDAQ stock exchange. 
Table 5 Regression results for Trip.com Group Ltd.

\begin{tabular}{|c|c|c|c|c|c|c|c|c|}
\hline \multirow{3}{*}{$\begin{array}{l}\text { Variable } \\
\text { Constant } \\
\text { LD }\end{array}$} & \multicolumn{2}{|c|}{$\begin{array}{l}\text { Coefficient } \\
\text { Model } 1\end{array}$} & \multicolumn{2}{|c|}{$\begin{array}{l}\text { Coefficient } \\
\text { Model } 2\end{array}$} & \multicolumn{2}{|c|}{$\begin{array}{l}\text { Coefficient } \\
\text { Model } 3\end{array}$} & \multicolumn{2}{|c|}{$\begin{array}{l}\text { Coefficient } \\
\text { Model } 4\end{array}$} \\
\hline & -10.865 & 0.175 & $-13.193^{* *}$ & 0.000 & $-18.383^{* *}$ & 0.000 & $-19.874^{* *}$ & 0.000 \\
\hline & $-3.842^{* *}$ & 0.000 & $-3.915^{* *}$ & 0.000 & -0.593 & 0.121 & $-2.102^{* *}$ & 0.000 \\
\hline$\triangle W N C C$ & 0.000 & 0.583 & 0.000 & 0.602 & 0.000 & 0.895 & 0.000 & 0.251 \\
\hline$N A S D A Q$ & $0.004^{* *}$ & 0.000 & $0.004^{* *}$ & 0.000 & $0.001^{* *}$ & 0.002 & $0.002^{* *}$ & 0.000 \\
\hline SSE & 0.005 & 0.200 & $0.001^{* *}$ & 0.002 & -0.001 & 0.376 & 0.001 & 0.120 \\
\hline$G P$ & 0.002 & 0.716 & 0.00 & 0.000 & $0.012^{* *}$ & 0.000 & 0.01 & 0.000 \\
\hline$O P$ & -0.113 & 0.102 & 0.010 & 0.550 & 0.037 & 0.160 & -0. & 0.037 \\
\hline VIX & $-0.071^{* *}$ & 0.005 & $0.000^{* *}$ & 0.000 & & & $-0.052^{* *}$ & 0.004 \\
\hline BOOK & & & & & $0.019^{* *}$ & 0.000 & $0.015^{* *}$ & 0.000 \\
\hline EXPE & & & & & $-0.099^{* *}$ & 0.000 & $-0.097^{* *}$ & 0.000 \\
\hline \multicolumn{9}{|c|}{ TRIP } \\
\hline \multicolumn{9}{|c|}{ Variance equation } \\
\hline$\alpha_{0}$ & & & $-1.253^{* *}$ & 0.001 & $-0.955^{* *}$ & 0.000 & $-1.069^{* *}$ & 0.000 \\
\hline$\alpha_{1}$ & & & $1.696^{* *}$ & 0.000 & $1.097^{* *}$ & 0.000 & $1.163^{* *}$ & 0.001 \\
\hline$\alpha_{2}$ & & & 0.129 & 0.505 & 0.068 & 0.734 & 0.036 & 0.856 \\
\hline $\begin{array}{l}\alpha_{3} \\
\text { Diagnostic }\end{array}$ & & & $-0.305^{*}$ & 0.030 & 0.387 & 0.085 & $0.498^{*}$ & 0.015 \\
\hline$N$ & 127 & & 127 & & 127 & & 127 & \\
\hline$R^{2}$ & 0.884 & & 0.861 & & 0.894 & & 0.908 & \\
\hline Adjusted $R^{2}$ & 0.878 & & 1.347 & & 0.887 & & 0.901 & \\
\hline$A I C$ & 3.367 & & 3.432 & & 2.924 & & 2.816 & \\
\hline$J-B$ & 2.928 & 0.231 & $6.073^{*}$ & 0.048 & 0.394 & 0.139 & 1.775 & 0.412 \\
\hline$A R C H$ & $22.999^{* *}$ & 0.000 & 0.659 & 0.419 & 0.807 & 0.777 & 0.027 & 0.871 \\
\hline$Q[1]$ & $20.238^{* *}$ & 0.000 & 0.685 & 0.408 & 0.841 & 0.772 & 0.028 & 0.867 \\
\hline$Q[20]$ & $66.937^{* *}$ & 0.000 & $36.032^{*}$ & 0.015 & 6.059 & 0.999 & 20.878 & 0.404 \\
\hline
\end{tabular}

Notes: BOOK, EXPE and TRIP represent the share prices of Booking Holding Inc., Expedia Group, Trip.com Group Ltd., respectively. NASDAQ, SSE, GP and OP denote NASDAQ Composite Index, Shanghai Stock Exchange Composite Index, gold spot price and WTI crude oil price, in that sequence. The probability value, $p$ is computed based on White heteroskedasticity-consistent standard errors and covariance, while $J-B$ stands for Jarque-Bera normality test. $A R C H$ denotes heteroscedasticity test for autoregressive conditional heteroscedasticity effect. $Q[1]$ and $Q[20]$ denote the Q-statistics of correlogram standardized squared residuals of lag 1 and 20 , respectively, for the detection of autocorrelation. ${ }^{* *}$ and ${ }^{*}$ denote that the variable is significant at $1 \%(p<0.01)$ and $5 \%(p<0.05)$, respectively

The estimated $\phi_{2}$ in Model 4 is statistically indifferent from zero, while the estimated $\phi_{3}$ is significantly different from zero at $5 \%$ significance level. Thus, positive and negative COVID19 shocks have symmetric effect for all the three leading OTCs in the tourism industry examined in this study. Furthermore, it takes nearly 1 day for the shocks to decay into half of its original size for TRIP [23]. As in the case of EXPE, shocks are also short-memory effect on the TRIP share price. Therefore, it is anticipated that the tourism share prices will recover soon after the pandemic threat is over, ceteris paribus.

\section{Conclusion}

The recent outbreak of COVID-19 pandemic has practically locked down and dampened the world economy with immediate effect on tourism related businesses. In this regard, Jamal and Budke (2020) are swift to provide scholarly discussions on tourism in the world with pandemics. The current study attempts to empirically quantify the nature and extent to which the tourism industry has been affected by this COVID-19, in the early stage. In particular, three largest OTCs, Booking Holdings Inc., Expedia Group and Trip.com Group Ltd. are selected for analysis to provide swift feedback to interested readers, investors and policymakers. Although these companies represent the OTCs in specific, but their global businesses are generally reflective of various key components of whole tourism industry, including travel services, tourism services, accommodation and transportation sectors. 
Daily data set spanning from October 2, 2019 to March 27, 2020 is used in this study. Few key findings regarding these tourism-related companies can be drawn from the numerical description and empirical modeling. First, tourism share prices are trending downwards after the lockdown was imposed on Wuhan and nearby cities. Second, COVID-19 pandemic outbreak has increased the investment risks by several times for these leading OTCs in the tourism industry. Third, the rates of price decline are growing faster and faster over time after the lockdown in the China-based leading company in the tourism industry in terms of transaction volume. Similar increasing rate of fall in share price is also observed for the two American-based leading OTCs in the world. This signals substantial increase in the investment risks related to the tourism industry in general, as a consequence of pandemic outbreak. Investors can learn a lesson here, such that in future, if there is any similar outbreak of pandemic or infectious disease that may threat human life, they should initially either stay away from, or short-sell tourism related shares if the authority allows that.

All these findings thus far are drawn from numerical description. Further analysis based on empirical modeling provides statistical evidence to support the expectation that the Wuhan lockdown because of the COVID-19 outbreak had exerted significant adverse effect on Booking Holdings Inc., Expedia Group and Trip.com Group Ltd. These companies typically derive their profits from tourism-related services, which are extensively cramped after the lockdown. This is the fifth finding.

Sixth, positive and negative COVID-19 shocks have temporary effect on these three leading OTCs in the tourism industry. Therefore, provided that there are no other deterrence factors, it is anticipated that the tourism share prices will rebound very soon after the global pandemic threat is over. Seventh, the change in world daily new coronavirus cases essentially has insignificant effect on the share prices of these leading OTCs. Probably, after the lockdown, investors do not bother about this change because of the expectation that tourists are unable or even unwilling to travel during this emergency period. In this conjunction, it has been established earlier that the unprecedented lockdown has immediate impact on tourism share prices. Knowing that lifting of lockdown depends very much on global COVID-19 development, it is expected that global investors are waiting for declining rate of change in daily world new confirmed COVID-19 cases for such clue [24]. Once the lockdown around the world is eventually lifted, business travelers may attempt to recommence their usual business activities (with precautionary measures) to make up their loss businesses during lockdown. Individual travelers may follow suit for pleasure or leisure trips after they have resumed their confidence, especially when the deadly pandemic fear is over. With the expectation that the tourism industry may revive soon, it is logic to anticipate that tourism share prices will rebound sooner as stock market reacts merely based on better business revenues expectation. As such, consider that tourism shares have slumped tremendously (nearly 30\% drop for BOOK and TRIP, and 45\% drop for EXPE) after the Wuhan lockdown imposition, investors may consider to buy the dips for foreseeable future capital gain.

Last but not least, the share prices of Booking Holdings Inc., Expedia Group and Trip.com Group Ltd. are significantly related to NASDAQ Composite Index, Shanghai Stock Exchange Composite Index, gold price and market volatility index. This indicates some degree of financial market inter-dependency among them. Notably, daily rate of change in world new confirmed COVID-19 cases has indirect negative effect on all the three tourism share prices. Besides, the share prices of these three companies are significantly related to one another. It reveals the inter-dependency within the tourism industry. Having said that, investors of tourism related shares must closely monitor not only the global and local general stock market sentiments as well as tourism industry specific news but also issues pertaining to the commodity markets.

Share price is the indicator of expected future business performance. The drastic slump of nearly $30 \%$ in share prices of Booking Holdings Inc. and Trip.com Group Ltd. alongside 
with approximately 45\% price plunge in Expedia Group during the lockdown indicates that investors expect a substantial drop in their revenues because of the pandemic outbreak. Remarkably, these three OTCs are typical tourism-related listed companies, that consolidate global travel services, tourism services, accommodation and transportation sectors for tourists. In this line of argument, the tourism industry as a whole is experiencing a business drop. Remarkably, tourism industry supports 319 million jobs, equivalent to $10 \%$ of global employment (Turner and Jus, 2019). As millions of jobs are dependent on this industry, it is important to ensure the survival of businesses in this industry, before they are able to progress into the future. Governments or central banks should implement policies to provide relief assistances such as corporate tax reduction incentives, job retention incentives, delay in existing loans payment and swift subsistence loans approval, to those needy businesses in the tourism industry amid the pandemic outbreak.

COVID-19 pandemic changes the norms of our routine operations and tourism industry is of no exception. For the future of tourism industry in the near term, tourism industry may offer promotions or value deals with emphasis given to facilities' cleanliness to attract early birds so as to partially recover the fixed costs and to maintain jobs. One foreseeable advantage in the road of recovery is that the oil price is currently $60 \%$ lower after the Wuhan lockdown. In the longer term, tourism businesses operators should turn this pandemic threat into opportunities by engaging technological innovations to increase efficiency and to reduce operation cost. Affordable tourism business operators such as Booking Holdings Inc. may even sponsor medical research to speed up the discovery of COVID-19 vaccines. No doubt tourists' confidence will be boosted once the vaccines are found. This investment will have long-term benefits for the whole tourism industry, while individual sponsors may enhance their brands and reputation from such corporate social responsibility engagement. Besides, applications of artificial intelligence and big data analytics may help substantially in the better understanding the desires and needs of travelers, for travel package promotion and sales improvement. Moreover, regional small industry players may need to look for mechanism to operate collaboratively to enhance their strength and resiliency.

To provide a swift feedback, this paper carefully chooses three typical tourism-related listed companies, in which their global business is generally reflective of various key components of tourism industry as a whole, including travel services, tourism services, accommodation and transportation sectors. Future studies are encouraged to examine each of these tourism sectors for individual effects.

\section{Notes}

1. Yuan is equivalent to about US\$0.14, in March 30, 2020.

2. China first reported the case to World Health Organization on December 31, 2019. See also, for instance, Burki (2020) and Jamal and Budke (2020) for briefings on the outbreak of the virus.

3. Both total confirmed cases and total deaths can be well-fitted by polynomial with of degree 5 , with very high degree of accuracy: $T C_{t}=0.02 t^{5}-2.12 t^{4}+101.74 t^{3}-1969.70 t^{2}+14320.00 t-26085.00$; $R^{2}=0.9931 ; T D_{t}=0.0007 t^{5}-0.09 t^{4}+4.43 t^{3}-87.59 t^{2}+657.95 t-1238.40 ; R^{2}=0.9957$. Where $T C$, $T D$ and $t$ denote total confirmed cases, total deaths and day, respectively.

4. Accessed on March 30, 2020, 07:41 GMT.

5. It had been fully lifted on April 8, 2020.

6. See Secon et al. (2020) for countries that are on lockdown because of COVID-19 as of March 20, 2020. UK followed suit on March 23, 2020 for an initial of three weeks' lockdown that could possibly be extended up to six months (Bienkov, 2020).

7. See for instance, Kasulis (2020) for news on how a single "super spreader," the "Patient 31" in Korea who travelled from Wuhan to Korea, had transmitted the virus to thousands of other patients. It is reported that some 5,016 (as of Mar 18, 2020) inflected patients in Korea were associated to the Shincheonenji church, where "Patient 31" had been there on February 9, 2020. 
8. Booking Holding Inc. and Expedia Group are included in this revised version for comparison purpose. Thanks to the two anonymous reviewers and an associate editor of this journal who recommended them.

9. More information on this company is available at US Securities and Exchange Commission (2020a) and www. bookingholdings.com/

10. Visit https://sec.report/CIK/0001324424 and www.expediagroup.com/about/ for more information on Expedia Group.

11. More information on this company is available at US Securities and Exchange Commission (2020b) and https://my.trip.com/pages/about-us/

12. Interested readers may visit the publicly available financial websites, for instance Investing.com and finance.yahoo.com for the current and historical share price of these tourism stocks.

13. See Crossley (2020) for official lockdown date of Wuhan city.

14. See Nelson (1991) for more information on EGARCH model.

15. A close examination on the data set (not shown here) reveals that the Booking Holdings Inc. share price peaked at $\$ 2,086.90$ on January 10,2020, and then started to fall on the next trading day onwards. Meanwhile, Trip.com Group Ltd. share price surged to \$36.91 on January 14, 2020 before it began to fall.

16. This is hypothetical, to make sense with the numerical description. If they keep them, they would observe an unrealized loss (loss on paper) while the final outcome is unknown yet (as long as they have not sold them), however.

17. Composite index itself is not tradable, but its derivatives such as futures, exchange-traded funds are.

18. EXPE experienced a single day price drop of $27.4 \%$ on November 7,2019 because of third-quarter earnings report that showed lower than expected sales and profits (Kalogeropoulos, 2019).

19. Gold shows a positive profit, with slightly smaller magnitude compared to the figure before lockdown, however.

20. Besides, crude oil price tumbled as US-Iran tensions lessen (Egan, 2020, The Star, 2020). Before this, crude oil price kept rising as Iran-US conflict hit the boiling point (O'Brien, 2020).

21. Earlier on, stationarity of the variables is examined. The results based on Augmented Dickey and Fuller (1972) and Phillips and Perron (1988) unit root tests suggest that all variables are not stationary in their levels, but they are stationary in their first-differenced forms. Subsequently, to avoid spurious OLS regression, these variables have to be cointegrated. In this conjunction, the Johansen (1991) cointegration test is used. The estimated results show that these variables are cointegrated. Hence, it is legitimate to adopt OLS regression technique in this study. Both sets of results are omitted here to conserve space.

22. $\frac{\ln (0.5)}{\ln (0.666)}=1.705$, see Olbrys and Majewska (2017).

23. $\frac{\ln (0.5)}{\ln (0.498)}=0.994$.

24. Thanks to an anonymous reviewer for sharing his/her thought.

\section{References}

Albulescu, C.T. (2020), "Coronavirus and financial volatility: 40 days of fasting and fear", Preprint. HAL02501814, available at https://hal.archives-ouvertes.fr/hal-02501814/document

Bienkov, A. (2020), "The UK coronavirus lockdown will last for up to 6 months and be policed with on-thespot fines", Business Insider US, 24 March, available at www.businessinsider.my/coronavirus-uklockdown-how-long-last-fines-covid-leaving-home

Burki, T. (2020), "Outbreak of coronavirus disease 2019", The Lancet Infectious Diseases, Vol. 20 No. 3, pp. 292-293, doi: 10.1016/S1473-3099(20)30076-1.

Chia, R.C.J., Liew, V.K.S. and Rowland, R. (2020), "Daily new covid-19 cases, movement control order and the Malaysian stock market returns", International Journal of Business and Society, Vol. 21, No. 2, pp. 553-568, available at: www. ijbs.unimas.my/images/repository/pdf/Nol21-no2-paper4.pdf

Crossley, G. (2020), "Wuhan lockdown 'unprecedented', shows commitment to contain virus: WHO representative in China", Reuters. 23 January, available at www.reuters.com/article/us-china-health-who/ 
wuhan-lockdown-unprecedented-shows-commitment-to-contain-virus-who-representative-in-china-idUSK BN1ZM1G9

Dickey, D.A. and Fuller, W.N. (1979), "Distribution of the estimators for autoregressive time series with a unit root", Journal of the American Statistical Association, Vol. 74 No. 366a, pp. 427-431.

Egan, M. (2020), "Crude oil plunges in stunning reversal", CNN Business, available at https://edition.cnn. com/business/live-news/stock-market-news-today-010820/h_9f380a49f90a31ab3ef4ec84c48a1ede

Jamal, T. and Budke, C. (2020), "Tourism in a world with pandemics: local-global responsibility and action", Journal of Tourism Futures, Vol. ahead-of-print No. ahead-of-print, doi: 10.1108/JTF02-2020-0014. 9 March

Johansen, S. (1991), "Estimation and hypothesis testing of cointegration vectors in Gaussian vector autoregressive models", Econometrica, Vol. 59 No. 6, pp. 1551-1580.

Kalogeropoulos, D. (2019), "Why Expedia stock lost 26\% in November: the travel booking business is getting more competitive", The Motley Fool. 4 December, available at www.fool.com/investing/2019/12/ 04/why-expedia-stock-lost-26-in-november.aspx

Kasulis, K. (2020), "Patient 31' and South Korea's sudden spike in coronavirus cases", Al Jazeera News. 3 March, available at www.aljazeera.com/news/2020/03/31-south-korea-sudden-spike-coronaviruscases, 20200303065953841.html

Lew, A.A. (1987), "The history, policies and social impact of international tourism in the people's republic of China", Asian Profile, Vol. 15 No. 2, pp. 117-128.

Nelson, D.B. (1991), "Conditional heteroskedasticity in asset returns: a new approach", Econometrica, Vol. 59 No. 2, pp. 347-370.

O'Brien, M. (2020), "Oil price keeps rising as industry eyes Iran-US conflict", AP News, 7 January, Available at https://apnews.com/c552a9b1a14be2ebf32a21ebd1f9506c

OECD (2020a), "OECD updates G20 summit on outlook for global economy", 15 April, Available at www. oecd.org/newsroom/oecd-updates-g20-summit-on-outlook-for-global-economy.htm

OECD (2020b), "Evaluating the initial impact of COVID-19 containment measures on economic activity", 14 April, Available at www. oecd.org/coronavirus/policy-responses/evaluating-the-initial-impact-of-covid19-containment-measures-on-economic-activity-b1f6b68b/

Olbrys, J. and Majewska, E. (2017), "Asymmetry effects in volatility on the major European stock markets: the EGARCH based approach", Quantitative Finance and Economics, Vol. 1 No. 4, pp. 411-427, available at www. aimspress.com/fileOther/PDF/QFE/QFE-01-00411.pdf

Oxford Analytica (2000), "Coronavirus may cut global growth to $2 \%$ in early 2020", Expert Briefings, 10 February, available at www.emerald.com/insight/content/doi/10.1108/OXAN-DB250564/full/ html

Phillips, P.C.B. and Perron, P. (1988), "Testing for a unit root in time series regression”, Biometrika, Vol. 75 No. 2, pp. 335-346.

Schaal, D. (2019), "Ctrip name change to trip.com group is now official", Skift, available at: https://skift. com/2019/09/09/ctrip-changing-name-to-trip-com-group-to-emphasize-international-business/

Secon, H. Frias, L. and McFall-Johnsen, M. (2020), "A running list of countries that are on lockdown because of the coronavirus pandemic", Business Insider US. 20 March, available at www. businessinsider.my/countries-on-lockdown-coronavirus-italy,202020-3? $r=U S \& \mid R=T$

Securities and Exchange Commission (2003), "Ctrip.com international, Ltd. initial public offering announcement", available at: www.sec.gov/Archives/edgar/data/1269238/000114554903001555/ u98691a2fv1za.htm

The Star (2020), "Oil price dives as US Iran tensions ease and on US crude build", 9 January, available at www.thestar.com.my/business/business-news/2020/01/09/oil-price-dives-as-us-irantensions-ease-and-on-us-crude-build

Thomala, L.L. (2020a), "Tourists in China 2018, by country of origin", Statista, 25 February, available at www.statista.com/statistics/234149/tourists-in-china-by-country-of-origin/

Thomala, L.L. (2020b), "International tourism spending of Chinese tourists 2008 to 2018", Statista, 22 January. available at www.statista.com/statistics/249702/international-tourism-expenditure-of-chinese-tourists/ 
Turner, R. and Jus, N. (2019), "Travel \& tourism economic impact 2019", World Travel \& Tourism Council (WTTC) Report, available at www.wttc.org/-/media/files/reports/economic-impact-research/regions2019/world2019.pdf

US Securities and Exchange Commission (2020a), "Booking holdings 2019 annual report form (10K)", 26 February, available at: https://ir.bookingholdings.com/static-files/92c3d5b6-8f42-4686-afc1f6bd61b94e06

US Securities and Exchange Commission (2020b), "Annual report pursuant to section 13 or 15(d) of the securities exchange act of 1934 for the fiscal year ended December 31, 2019", available at https:// investors.trip.com/static-files/71a63eec-992b-49ea-92ea-342bdb1130fe

Worldometers (2020), "COVID-19 coronavirus pandemic", available at www.worldometers.info/ coronavirus/

\section{Further reading}

Hernandez, M. Scarr, S. and Sharma, M. (2020), "The Korean clusters: how coronavirus cases exploded in South Korean churches and hospitals", Reuters, available at https://graphics.reuters.com/CHINAHEALTH-SOUTHKOREA-CLUSTERS/0100B5G33SB/index.html

Liew, V.K.S. (2004), "Which lag length selection criteria should we employ?", Economics Bulletin, Vol. 3 No. 33, pp. 1-9.

World Health Organization (2020), "Rolling updates on coronavirus disease (COVID-19)", available at www.who.int/emergencies/diseases/novel-coronavirus,202019/events-as-they-happen

\section{Corresponding author}

Venus Khim-Sen Liew can be contacted at: ksliew@unimas.my

For instructions on how to order reprints of this article, please visit our website: www.emeraldgrouppublishing.com/licensing/reprints.htm

Or contact us for further details: permissions@emeraldinsight.com 